\title{
Renal artery embolism on the contralateral kidney after a radical nephrectomy
}

\section{Radikal nefrektomi sonrası karşı taraf böbrekte renal arter embolisi}

\author{
Abdullah GÜL', Serhat YENTÜR², Mesut ÖZGÖKÇE ${ }^{3}$
}

\section{ABSTRACT}

Renal artery occlusion results commonly from thromboembolism to renal artery from distant vascular system. Hyperhomocysteinemia is one of the hereditary hypercoagulability reasons. In order to elicit ethiology in the cases of arterial thrombosis, necessity of hypercoagulopathy screening tests is still controversial. Diagnosis of renal artery thromboembolism should be remembered in the patients who develop postoperative anuria and renal angiographic intervention must be performed immediately for thrombolytic therapy after renovascular imaging. We report a case of a 54-year-old woman with renal artery embolism on the contralateral kidney due to hyperhomocysteinemia after an open left radical nephrectomy.

Keywords: Acute renal failure, hyperhomocysteinemia, renal artery embolism

\section{INTRODUCTION}

Renal artery embolism is a rarely seen reason of renal failure and it's diagnosis is difficult. Renal function can be reversible after renal revascularization thanks to early diagnosis and treatment ${ }^{1}$.

There are two causes of acute renal artery occlusion; thrombus and renal artery embolism. Acute thrombosis is defined as a thrombus obstruction caused by renal vascular system. Trauma and instrumentation are the most important resources for the thrombosis. As for thromboembolism, it is known as the most common reason of the renal artery occlusion due to thrombosis originating from the distant vascular areas ${ }^{2}$. öz

Renal arter tıkanıklığına, çoğunlukla uzak bölgelerdeki vasküler sistemden renal artere gelen tromboemboli neden olur. Hiperhomosisteinemi, kalıtımsal hiperkoagülopati nedenlerinden birisidir. Arteriyel tromboz vakalarında, etiyolojiyi ortaya çıkarmak için hiperkoagülopati tarama testlerinin gerekliliği hala tartışmalıdır. Ameliyat sonrası anüri gelişen hastalarda renal arteriyel tromboemboli akla gelmeli ve renovasküler görüntüleme sonrası anjiografik trombolitik tedavi acilen uygulanmalıdır. Sol açık radikal nefrektomi sonrası karşı böbrekte hiperhomosisteinemiye bağlı renal arter embolisi gelişen 54 yaşında kadın hasta sunmaktayız.

Anahtar kelimeler: Akut böbrek yetmezliği, hiperhomosisteinemi, renal arter embolisi

The lack of Antithrombin III, Protein C and Protein S, the resistance of active protein $\mathrm{C}$ (the Factor $\mathrm{V}$ Leiden polymorphism), Prothrombin 20210A polymorphism, hyperhomocysteinemia, dysplasminogenemia, dysfibrinogenemia, high plasminogen activator inhibitor (PAI) levels (PAI-1 4G/5G polymorphism) and increased factor VIII levels are considered responsible for hereditary hypercoagulability while the presence of antiphospholipid, thrombocythemia, dysproteinemia, heparin induced thrombocytopenia, estrogen treatment, malignancy, pregnancy, bed rest, operation and trauma result in acquired hypercoagulability ${ }^{3,4}$.

Recently, significant relationship between the development of venous thrombosis and hereditary hyper-

Received: 19.09 .2017

Accepted: 23.12.2017

${ }^{1}$ Department of Urology, The Ministry of Health, University of Health Sciences, Van Education \& Research Hospital, Van, Turkey

2Department of Urology, Medical Park Hospital, Elazıg, Turkey

${ }^{3}$ Deparment of Radiology, Yuzuncu Yil University, School of Medicine, Van, Turkey

Yazışma adresi: Abdullah Gül, Department of Urology, The Ministry of Health, University of Health Sciences, Van Education \& Research Hospital, Van, Turkey

e-mail: dr_abdullahgul@hotmail.com 
coagulability has been demonstrated. Besides, local or diffuse atherosclerosis has been associated with arterial thrombosis 5 . Much as some studies have demonstrated a significant role of hypercoagulability in arterial thrombosis, others emphasize the less importance of hypercoagulopathy screening tests in the etiology of arterial thrombosis cases ${ }^{4,6-8}$.

In this paper we present hyperhomocysteinemia induced renal artery embolism case on the contralateral kidney following radical nephrectomy and aimed to discuss it in the light of the current literature.

\section{CASE PRESENTATION}

A 54-year-old white female patient with a left kidney mass found incidentally via ultrasonography was referred to our clinic. Physical examination, serum biochemistry and urine analysis were normal while contrast-enhanced computed tomography scan revealed a $85 \times 63 \mathrm{~mm}$, contrast enhanced, solid mass located on the left kidney upper pole and several lymph nodes with the largest one measured as 11,7 $\mathrm{mm}$ in the left paraaortic area (Figure 1). Paraneoplastic syndrome wasn't detected. On the preopera-

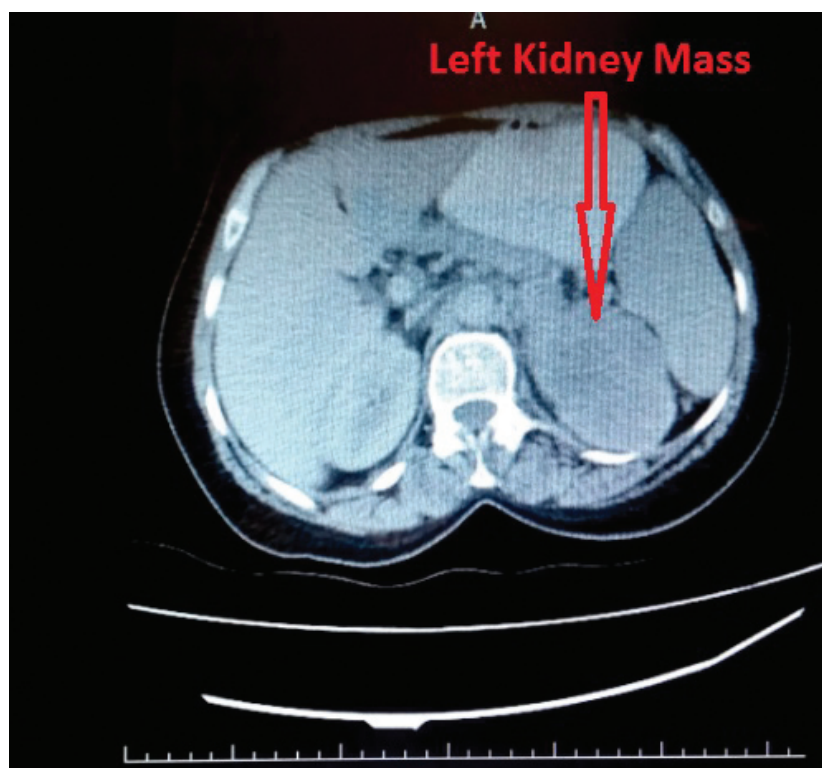

Figure 1. Preoperatively CT image of the patient. CT of the abdomen with intravenous contrast demonstrated a $85 \times 63 \mathrm{~mm}$, well-circumscribed, solid mass in the upper pole region of the left kidney (arrow). tive renal doppler ultrasonography thrombosis was seen only on the left renal vein, which didn't extend to the vena cava inferior.

A left open radical nefrectomy was planned for the patient. Twelve hours before the surgery, $6000 \mathrm{IU}$ low molecular weight heparin was administered subcutaneously to the patient. The left radical nephrectomy with left paraaortic lymph node dissection was performed and the operation took about $110 \mathrm{~min}$ utes. While it was detected HBG:11.7 g/dl, HTC:36 and serum creatinine: $1.61 \mathrm{mg} / \mathrm{dl}$ on the first postoperatively blood count, creatinine level was $2.79 \mathrm{mg} /$ $\mathrm{dl}$ after four hours of surgery. It was initially thought to be analgesic-associated nephropathy. Then, the patient fell into anuria and serum BUN and creatinine levels increased to $5.22 \mathrm{mg} / \mathrm{dl}$ and $110 \mathrm{mg} / \mathrm{dl}$ after twelve hours of operation, respectively. Since it was thought as acute renal failure, ultrasound scan of abdomen including renal doppler was planned. Doppler examination revealed an embolism in the right

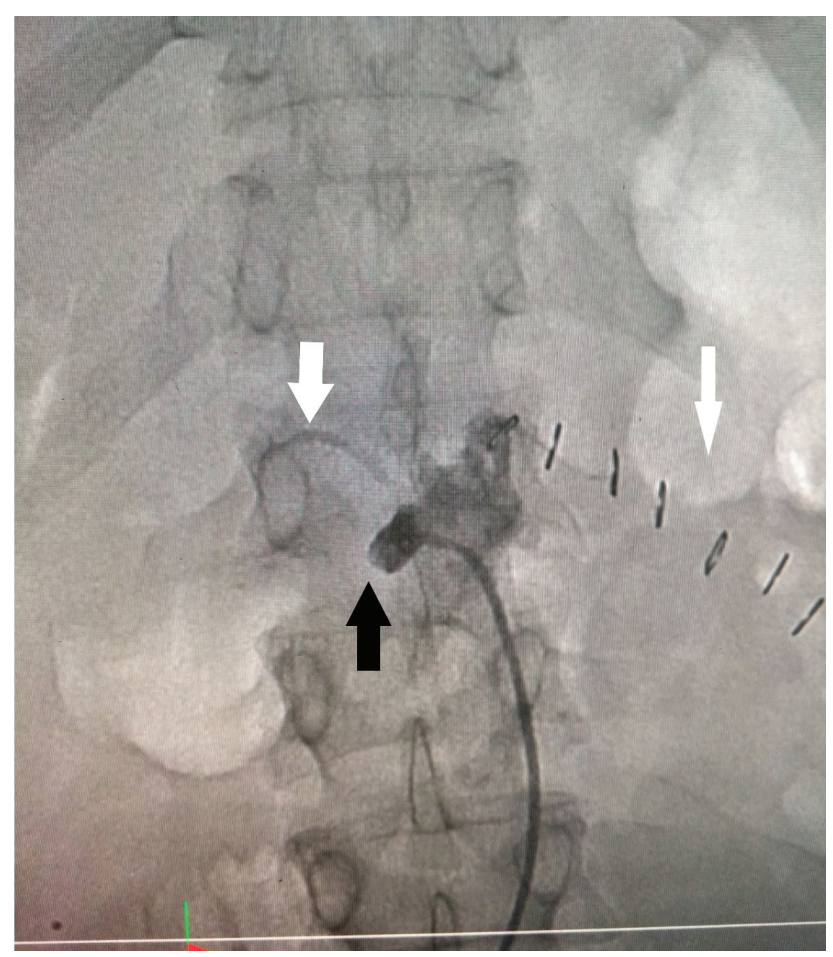

Figure 2. An angiographic image of the abdominal aorta. Angiography revealed total occlusion in the right main renal artery (black arrow). Contrast flow to a branch of abdominal aorta (thick white arrow) and skin staples on the area of the skin incision of left nephrectomy (thin white arrow) can be seen. 
renal artery. The patient was referred immediately to another hospital for renal angiographic intervention for thrombolysis however that procedure failed as shown in figure 2. Antithrombin III, antiphospholipid antibody, factor $\mathrm{V}$ Leiden polymorphism, protein $\mathrm{C}$, protein $\mathrm{S}$, homocysteine levels were evaluated to determine prone to the thrombosis. The total plasma homocysteine level was high as $128.2 \mu \mathrm{mol} / \mathrm{L}$ (the reference range for the female patient: 3.7-10.4 $\mu \mathrm{mol} / \mathrm{L})$. Hemodialysis treatment was performed until the kidney transplantation, which was performed 6 months later.

\section{DISCUSSION}

Since acute renal embolism is very rare and highly difficult to diagnose, it can only be detected if there is a clinical suspicion. It may occur in patients with atrial fibrillation, cardiac valve diseases, endocarditis or any embolism history. Clinical presentation may vary from asymptomatic to sudden severe abdominal or lumbar pain ${ }^{9,10}$.

In our case, atrial fibrillation was detected neither during the operation nor in intensive care unit after the early hours of operation. The patient had no history of embolism or cardiovascular diseases. There was no sign of right renal artery infarct symptom and complaint of specific pain. The only factor that led us to make diagnosis was the ratio of BUN/Crea which was compatible with the prerenal acute renal failure. Because of the high serum creatinine level, contrast-enhanced computed tomography scanning could not be carried out and renal artery embolism was revealed by renal doppler ultrasonography.

Although there is no standard treatment for the renal artery embolism, angiographic intervention using either with the thrombolytics alone or with anticoagulant agents can be preferred primarily ${ }^{11-13}$. However, thrombolytic therapy should be started within the first 90-180 minutes when vitality of the kidney tissue is considered to be alive. If the ischemia time takes more than 180 minutes, it will cause irreversible renal parenchymal damage ${ }^{11}$. In contrast, some studies reported successful revascularization results even after 72 hours and recovery of renal function after some obstructive cases ${ }^{14,15}$.

Blum et al. ${ }^{11}$ reported that loss of renal tissue was observed in 30 of 32 surgically treated patients ( 27 embolectomy, 3 nephrectomy, 2 bypass surgery), however no renal tissue loss was seen in two patients with less than 3 hours of occlusion. Today the use of surgical treatment of renal embolism is very limited because of the high morbidity and limited kidney conservation rates. Under these conditions we chose renal angiographic thrombolytic therapy in this case.

Hyperhomocysteinemia was found the main reason of embolism in our case. Homocysteinemia -disorder of methionin metabolism- is a rare, autosomal recessively inherited disease and linked to an increased incidence of arterial and venous renal thrombosis ${ }^{17,18}$.

Several hypotheses have been suggested about how the high serum homocysteine levels cause thrombosis and atherosclerosis. One of these hypotheses, which is also supported by several experimental studies is that; homocysteine is toxic to the vascular endothelial structure and coagulation mechanisms ${ }^{19}$. Another hypothesis suggests that hyperhomocysteinemia is a sign of abnormal methionin metabolism that effects DNA and cell membrane ${ }^{20}$.

It has been shown that there is a proportional relationship between the high serum homocysteine levels and atheriosclerotic coronary heart disease. When the concentration of total homocysteine blood level increases by $5 \mu \mathrm{mol} / \mathrm{L}$, the cardiovascular disease risk increases about 1.6 to 1.8 fold $^{21,22}$.

As a result, renal artery thromboembolism diagnosis should be remembered in patients who develop postoperative anuria, and it should not be forgotten that post-surgical pain may be clinically misleading in these patients. It is also important to perform the renovascular imaging as early as possible. 


\section{REFERENCES}

1. Rodriguez Benitez P, Gomez Campdera FJ, Perez Garcia R, et al. El infarto renal agudo: una patología infradiagnosticada y tratable. Nefrologia. 1999;19:414-21.

2. Şamlı M, Doğulu Ç, Demirhan N. Unilateral renal tromboz ve hiperkoagulabilite. ACU Sağlık Bilimleri Dergisi. 2011(2):152-5.

3. Abramson N, Abramson S. Hypercoagulability: Clinical assessment and treatment. Review article. Southern Medical Journal. 2001;94:1013-20. https://doi.org/10.1097/00007611-200194100-00015

4. Thomas DP, Roberts HR. Hypercoagulability in venous and arterial thrombosis. Annals of Internal Medicine. 1997;126:638-44. https://doi.org/10.7326/0003-4819-126-8-199704150-00009

5. Rosendaal FR. Risk factors for venous thrombotic disease. Thromb Haemost. 1999;82:610-9. https://doi.org/10.1055/s-0037-1615887

6. Wilhelmsen L, Svardsudd K, Korsan-Bengtsen K, et al. Fibrinogen as a risk factor for stroke and myocardial infarction. $\mathrm{N}$ Engl J Med. 1984;311:501-5. https://doi.org/10.1056/NEJM198408233110804

7. Meade TW, Mellows S, Brozovic M, et al. Haemostatic function and ischaemic heart disease:principal results of the Northwick Park Heart Study. Lancet. 1986;2:533-7. https://doi.org/10.1016/S0140-6736(86)90111-X

8. Libby P, Mach F, Schönbeck U, et al. Regulation of the thrombotic potential of atheroma. Thromb Haemost. 1999;82:736-41. https://doi.org/10.1055/s-0037-1615905

9. Hall SK. Acute renal vascular occlusion: an uncommon mimic. J Emerg Med. 1993;11:691-700. https://doi.org/10.1016/0736-4679(93)90628-K

10. Theiss M, Wirth MP, Dolken W, et al. Spontaneous thrombosis of the renal vessels. Rare entiries to be considered in differential diagnosis of patients presenting with lumbar flank pain and hematuria. Urol Int. 1992;48:441-5. https://doi.org/10.1159/000282374

11. Blum $U$, Billmann P, Krause $T$, et al. Effect of local low dose thrombolysis on clinical outcome in acute embolic renal artery occlusion. Radiology. 1993;189:549-554. https://doi.org/10.1148/radiology.189.2.8210388
12. Gasparini M, Hofmann R, Stoller M. Renal artery embolism: Clinical features and therapeutic options. J Urol. 1992;147:567-72. https://doi.org/10.1016/S0022-5347(17)37308-1

13. Ramamoorthy SL, Vasquez JC, Taft PM, et al. Nonoperative management of acute spontaneous renal artery dissection. Ann Vasc Surg. 2002;16:157-62. https://doi.org/10.1007/s10016-001-0154-0

14. Eurvilaichit C, Tirapanich W, Thongborisute E. Renal artery embolism: therapy with intraarterial streptokinase infusion. J Med Assoc Thai. 1999;82:978-83.

15. Inoue $\mathrm{T}$, Iwamura $\mathrm{H}$, Kanematsu $\mathrm{A}$, et al. Renal artery embolism treated by selective intraarterial infusion of tissue plasminogen activator: report of 2 cases. [Article in Japanese] Hinyokika Kiyo. 1997;43:655-9.

16. Alexander RW, Pratt CM, Ryan TJ, et al. ST segment elevation myocard infarction: Clinical presentation, diagnostic evaluation, and medical management; in The Heart (Eds). Fuster V, Alexander RW, O'Rourke RA: $11^{\text {th }}$ edition. The Mc GRAW-Hill Comp., 2004. Chapter 52. 1277-1350.

17. Ballal RS. Homocysteine: Update on a new risk factor. Cleve Clin J Med. 1997;64:543-9. https://doi.org/10.3949/ccjm.64.10.543

18. Salden A, Keeney S, Hay CRM, et al. The C677T MTHFR variant and the risk of venous thrombosis. $\mathrm{Br} J$ Haematol. 1997;99:472.

19. Rees MM, Rodgers GM. Homocysteinemia: association of a metabolic disorder with vascular disease and thrombosis. Thromb Res. 1993;71:337-59. https://doi.org/10.1016/0049-3848(93)90160-P

20. Blom HJ, van der Molen EF. Pathobiochemical implications of hyperhomocysteinemia. Fibrinolysis. 1994;8:86-7. https://doi.org/10.1016/0268-9499(94)90257-7

21. Nygard O, Vollset SE, Refsum H, et al. Total plasma homocysteine and cardiovascular risk profile. JAMA. 1995;274:1526-33. https://doi.org/10.1001/jama.1995.03530190040032

22. Ubbink JB, VanderMerWe A, Vermaak WJH, et al. Homocysteinemia and response to vitamin supplements Clinical Investig. 1993;71:993-8. https://doi.org/10.1007/BF00180030 